\title{
CTNNB1 wt Allele
}

National Cancer Institute

\section{Source}

National Cancer Institute. CTNNB1 wt Allele. NCI Thesaurus. Code C52512.

Human CTNNB1 wild-type allele is located in the vicinity of 3p21 and is approximately 41 $\mathrm{kb}$ in length. This allele, which encodes catenin beta-1 protein, plays a role in the mediation of both adherens junction arrangement and the Wnt protein signaling pathway. 